\title{
PENGARUH SERTA PENTINGNYA FAKTOR KEPUASAN KERJA DAN \\ SEMANGAT KERJA DALAM MENINGKATKAN PRODUKTIVITAS \\ KERJA PEGAWAI DI SUATU PERUSAHAAN, INSTANSI ATAU \\ ORGANISASI
}

\author{
Oleh: \\ ANI WAHYUNI, 17002114 \\ Psikologi Manajemen-Jurusan Admnistrasi Pendidikan \\ Fakultas Ilmu Pendidikan, Universitas Negeri Padang \\ E-mail : aniwahyuni151@gmail.com
}

\begin{abstract}
ABSTRAK
Artikel ini bertujuan untuk menggambarkan dan menjelaskan mengenai : (1) Kepuasan kerja, semangat kerja dan produktivitas kerja pegawai. (2) Mengetahui seberapa besar tingkat kepuasan kerja, semangat kerja dan produktivitas kerja pegawai disuatu perusahaan atau organisasi, serta (3) Mengetahui seberapa besar pengaruh serta pentingnya faktor kepuasan kerja dan semangat kerja dalam meningkatkan produktivitas kerja pegawai. Kepuasan kerja dan semangat kerja sangat berpengaruh dalam meningkaktkan produktivitas kerja pegawai di suatu perusahaan/organisasi, dimana jika kepuasan kerja dan semangat kerja naik maka secara otomatis tingkat produktivitas kerja pegawai disuatu perusahaan juga akan ikut naik. Adapun faktor yang mempengaruhi kepuasan kerja : (1) pekerjaan itu sendiri, (2) hubungan dengan atasan, (3) teman sekerja, (4) promosi, (5) gaji dan upah.Indicator yang mempengaruhi semangat kerja yaitu: (1) naiknya produktivitas karyawan (2) tingkat absensi rendah, (3) labour trun over. Indicator yang memepengaruhi produktivitas kerja pegawai yaitu: (1) kemampuan, (2) meningkatkan hasil yang dicapai, (3) semangat kerja, (4) pengembangan diri, (5) mutu, (6) efisiensi.
\end{abstract}

Kata Kunci : Kepuasan Kerja, Semangat Kerja, Produktivitas Kerja Pegawai 


\section{A. PENDAHULUAN}

\section{Latar Belakang}

Manusia merupakan faktor utama pada setiap kegiatan yang di dalamnya terdapat berbagai bidang khususnya dalam berorganisasi. Perusahaan harus memikirkan bagaimana cara mengembangkan sumber daya manausianya agar dapat mendorong kemajuan baik bagi perusahaan maupun karyawan. Sumber daya yang berkualitas adalah produktivitas pada masing-masing posisi yang mereka pegang. Produktivitas ini merupakan suatu hasil kerja dari karyawan. Salah satu produktivitas kerja karyawan adalah sikap mental.Apabila karyawan tidak mempunyai kepuasan kerja dalam bekerja dan menjadikan tugasnya sebuah beban, maka peningkatan produktivitas kerja karyawan tidak akan terpenuhi, dan produktivitas kerja karyawan pun menurun. Penurunan produktivitas sering terjadi akibat ketidaknyamanan dalam bekerja sehingga menimbulkan terjadinya penurunan semangat dalam bekerja.

Factor kepuasan kerja dan semangat kerja pegawai sangat berpengaruh dan sangat penting bagi perusahaan ataupun organisasi, karena dengan adanya kepuasan bagi pegawai, diharapkan nantinya akan semakin meningkatkan kinerja dan berimbas pada peningkatan produktivitas perusahaan. kepuasan kerja pada dasarnya merupakan hal yang bersifat individual, setiap individual memiliki tingkat kepuasan kerja yang berbeda-beda sesuai dengan keinginan dan sistem yang dianutnya. Kepuasan kerja adalah perasaan atau sikap seseorang terhadap pekerjaan yang dilakukannya. Semakin banyak aspek-aspek dalam pekerjaan yang sesuai dengan keinginan individu tersebut, maka semakin tinggi tingkat kepuasan yang dirasaknnya, sebaliknya semakin sedikit aspek-aspek dalam pekerjaan yang sesuai dengan keinginan individu, maka semakin rendah tingkat kepuasan yang dirasakannya (Suritsno, 2015:76). Sedangkan Nitisemito (199:12) semangat kerja adalah pekerjaan 
dilakukan secara baik, lebih giat sehingga pekerjaan dapat diselesaikan lebih cepat dengan produktivitas akan meningkat.(Ermita 2012) Pegawai dapat melaksanakan pekerjaan secara optimal apabila ia memiliki semangat kerja. Pegawai yang memiliki semangat cenderung bertanggung jawab terhadap pekerjannya. Disamping itu pegawai yang bersemangat akan terlihat dari kesungguhannya bekerja (antusias), berpartisipasi dalam kegiatan kantor, berinisitif dan kreatif, serta sanggup untuk bekerja sama dengan pegawai lainnya. Kerja yang tinggi akan melahirkan produktivitas kerja yang tinggi pula.

\section{Rumusan Masalah}

Berdasarkan latar belakang dari uraian diatas, maka dapat kita simpulkan bahwa permasalahan yang ada dalam artikel ini adalah kita harus memahami terlebih dari apa itu pengertian kepuasaan kerja, semangat kerja, dan produktivitas kerja, serta kita harus memahami seberapa besar tingkat kepuasan kerja dan semangat kerja dalam meningkatkan produktivitas kerja pegawai di suatu perusahaan atau organisasi, sehingga dengan memahami permasalahan tersebut, maka kita dapat mengetahui apa pengaruh dan seberapa pentingnya faktor kepuasan kerja dan semangat kerja dalam meningkatkan produktivitas kerja pegawai di suatu perusahaan atau organisasi.

\section{Tujuan}

Adapun tujuan dari artikel ini adalah (1) Untuk mengetahui dan memahami apa itu kepuasan kerja, semangat kerja, dan produktivitas kerja pegawai (2) Untuk mengetahui seberapa besar tingkat kepuasan kerja, semangat kerja dan produktivitas kerja pegawai di suatu perusahaan atau organisasi. (3) Untuk mengetahui seberapa besar pengaruh serta pentingnya faktor kepuasan kerja dan semangat kerja dalam meningkatkan produktivitas kerja pegawai. 


\section{B. PEMBAHASAN}

\section{Ringkasan Artikel}

\section{a. Kepuasan Kerja}

Menurut Davis dan Newstown (1994) kepuasan kerja adalah seperangkat perasaan pegawai tentang menyenangkan atau tidaknya pekerjaan mereka. Kepuasan kerja pada umumnya mengacu pada sikap seorang pegawai. Kepuasan kerja menunjukkan kesesuaian antara harapan seseorang yang timbul dan imbalan yang disediakan pekerjaan.

Kepuasan kerja menurut Handoko (2001) adalah keadaan emosional yang menyenangkan atau tidak menyenangkan dengan mana para karyawan memandang pekerjaan mereka. (Ilahi, Mukzam, and Prasetya 2017) Kepuasan kerja mencerminkan perasaan seseorang terhadap pekerjaannya. Ini Nampak dalam sikap positif karyawan terhadap pekerjaan dan segala sesuatu yang dihadapi dilingkungan kerjanya. Sementara itu Hasibun (2013) menyatakan bahwa kepuasan kerja adalah sikap emosional yang menyenangkan dan mencintai pekerjaannya. Menurut Luthans (2006) kepuasan kerja adalah hasil dari persepsi karyawan mengenai seberapa baik pekerjaan mereka memberikan hal yang dinilai penting.

Dalam buku Psikologi Perusahaan (Mangkunegara, 1993) pegawai akan merasa puas dalam bekerja apabila aspek-aspek pekerjaan dan aspek aspek dirinya menyokong dan sebaliknya jika aspek-aspek tersebut tidak menyokong, pegawai akan merasa tidak puas.

\section{Factor yang Mempengaruhi Kepuasan Kerja}

Menurut Widodo (2015:176) berpendapat ada factor penentu kepuasan kerja yaitu: 
1. Pekerjaan itu sendiri (Work It Self). Setiap pekerjaan memerlukan suatu keterampilan tertentu sesuai dengan bidangnya masing-masing.

2. Hubungan dengan atasan (Supervision), hubungan fungsional mencerminkan sejauh mana atasan membantu tenaga kerja untuk memuaskan nilai-nilai yang penting bagi tenaga kerja.

3. Teman sekerja (Workers), teman kerja merupakan factor yang berhubungan antara pegawai dengan atasannya dan pegawai lain, baik yang sama maupun yang berbeda jenis pekerjaannya.

4. Promosi (promotion), promosi merupakan factor yang berhubungan dengan ada tidaknya kesempatan untuk memperoleh peningkatan.

5. Gaji dan Upah (Pay), Gaji dan upah merupakan factor pemenuhan kebutuhan hidup pegawai yang dianggap layak atau tidak.

Dalam buku Manajemen Sumber Daya Manusia (Sutrisno, 2009) faktot faktor yang mempengaruhi kepuasan kerja yaitu:

1. Faktor psikologi, merupakan faktor yang berhubungan dengan kejiwaan karyawan, yang meliputi minat, ketentraman dalam kerja, sikap terhadap kerja, bakat, dan keterampilan.

2. Faktor sosial, merupakan faktor yang berhubungan dengan interaksi soaial antar karyawan maupun karyawan dngan atasan.

3. Faktor fisik, merupakan faktor yang berhubungan dengan kondisi fisik karyawan, meliputi jenis pekerjaan, pengaturan waktu, dan waktu istirahat, perlengkapan kerja, keadan ruangan, suhu, penerangan, pertukaran udara, kondisi kesehatan karyawan, umur dsb.

4. Faktor finansial, merupakan faktor yang berhubungan dengan jaminan serta kesejahteraaan karyawan, yang meliputi sistem dan besarnya gaji, jaminan sosila, macam-macam tunjangan, fasilitas yang diberikan, promosi dsb. 


\section{b. Semangat Kerja}

Sastrahadirwiryo (2002:282) menyatakan bahwa semangat kerja adalah suatu kondisi rohaniah, atau perilaku individu tenaga kerja dan kelompok yang menimbulkan kesenangan yang mendalam pada diri tenaga kerja untuk bekerja dengan giat dan konsekuen dalam mencapai tujuan yang telah ditetapkan organisasi. Hasibun (2013) semangat kerja adalah keinginan dan kesungguhan seseorang mengerjakan pekerjaannya dengan baik serta disiplin untuk mencapai produktivitas yang maksimal.

\section{Indicator Semangat Kerja}

(Wibisono 2017) Indicator semangat kerja yang dikemukakan oleh Alex S. Nitisemito, diantaranya:

1. Naiknya produktivitas karyawan

Karyawan yang semangat kerjanya tinggi cenderung melaksanakan tugas-tugas sesuai waktu, tidak menunda pekerjaan dengan sengaja, serta mempercepat pekerjaan dan sebagainya.

2. Tingkat absensi rendah

Tingkat absensi rendah merupakan salah satu indikasi meningkatnya semangat kerja, karena Nampak bahwa persentase absen seluruh karyawan rendah. Dimensi absensi yang rendah diukur dengan menggunakan empat indicator, yaitu: 1) Cuti, 2) Keterlambatan, 3) Alfa, 4) Sakit.

3. Labour Turn Over

Tingkat keluar masuk karyawan yang menurun merupakan salah satu indikasi meningkatkanya semangat kerja. Hal ini dapat disebabkan oleh kesenangan mereka bekerja pada perusahaan tersebut. 


\section{c. Produktivitas Kerja Pegawai}

Produktivitas adalah ukuran efisiensi produktif. Suatu perbandingan antara hasil keluaran dan masukan. Masukan sering dibatasi dengan tenaga kerja, sedangkan keluaran diukur dengan satuan fisik, bentuk, dan nilai (Sutrisno, 2015:99)

Syarif dalam Widodo (2015:219), mengatakan produktivitas adalah hubungan antara kualitas yang dihasilkan dengan jumlah kerja yang dilakukan untuk mencapai hasil itu. Menurut Hasibuan produktivitas kerja merupakan perbandingan yang dimiliki baik secara peroragan ataupun tim di dalam orgnisasi tersebut.

\section{Indicator Produktivitas Kerja}

Indicator produktivitas kerja menurut Sutrisno (2015) sebagai berikut:

1. Kemampuan, mempunyai kemampuan untuk melaksanakan tugas, kemampuan karyawan sangat bergantung pada keterampilan yang dimiliki serta profesionalisme mereka dalam bekerja, ini memberikan daya untuk menyelesaikan tugas tugas yang diembannya pada mereka.

2. Meningkatkan hasil yang dicapai, hasil merupakan salah satu yang dapat dirasakan baik oleh yang mengerjakan maupun yang menikmati hasil pekerjaan tersebut. Jadi, upaya untuk memanfaatkan produktivitas kerja bagi masing-masing yang terlibat dalam suatu pekerjaan.

3. Semangat kerja, ini merupakan usaha untuk lebih baik dari hari kemarin. Indicator ini dapat dilihat dari etos kerja dan hasil yang dicapai dalam satu hari kemudian dibandingkan dengan hari sebelumnya.

4. Pengembangan diri, dapat dilakukan dengan melihat tantangan dan harapan dengan apa yang dihadapi. Sebab semakin kuat tantangannya, 
pengembangan diri mutlak dilakukan. Begitu juga harapan untuk menjadi lebih baik pada gilirannya akan sangat berdampak pada keinginan karyawan untuk meningkatkan kemampuan.

5. Mutu, yang merupakan hasil pekerjaan yang dapat menunjukan hasil kerja seseorang pegawai. Jadi meningkatkan mutu bertujuan untuk meningkatkan mutu bertujuan untuk meningkatkan hasil yang terbaik yang pada gilirannya akan sangat berguna bagi perusahaan dan dirinya sendiri

6. Efisiensi, yaitu perbandingan antara hasil yang dicapai dengan keseluruhan sumber daya yang digunakan. Masukan dan keluaran merupakan aspek produktivitas yang memberi pngaruh yang dignifikan bagi pegawai.

\section{KAJIAN ANALITIS}

\section{a. Kepuasan Kerja}

Berdasarkan pendapat para ahli dari landasan teori diatas maka dapat kita simpulkan bahwa kepuasan kerja adalah suatu sikap seseorang individu atau pegawai atas perasaan yang menyenangkan dan tidak menyenangkan yang berhubungkan dengan pekerjaanya ataupun kondisi dirinya.

\section{b. Semangat Kerja}

Berdasarkan pendapat para ahli dari landasan teori diatas maka dapat kita simpulkan bahwa semangat kerja adalah gambaran perasaan seseorang dimana mempunyai keinginan dan kesungguhan dalam melaksanakan pekerjaannya dengan baik, giat, disiplin dan konsekuen dalam rangka untuk mencapai tujuan yang telah ditetapkan secara optimal. Semangat kerja akan menunjukan sejauh mana pegawai dalam melakukan

tugas dan tanggung jawabnya di dalam perusahaan. semangat kerja 
pegawai dapat dilihat dari kehadiran, kedisiplinan, ketetapan waktu menyelesaikan pekerjaan dan tanggung jawab.

\section{c. Produktivitas Kerja}

Berdsarkan pendapat para ahli dari landasan teori diatas maka dapat kita simpulkan bahwa produktivitas kerja adalah ukuran efisiensi dan efektivitas produktif. Produktivitas bisa dikatakan rasio dari hasil kerja dengan waktu yang dibutuhkan untuk menghasilkan produk dan jasa dari seseorang tenaga kerja maupun perusahaan, produktivitas dalam perusahaan jasa diartikan kemampuan organisasi jasa mempergunakan input (tenaga kerja, biaya, dan bahan) untuk menawarkan jasa atau melayani dengan kualitas sesuai dengan harapan maupun harapan konsumen.

Produktivitas merupakan salah satu komponen penting yang harus dimiliki oleh perusahaan apabila ingin mencapai tujuan yang telah ditetapkan perusahaan. dalam kegiatannya perusahaan harus mampu meningkatkan produktivitas kerja dari waktu kewaktu, hal ini berkaitan dengan sumber daya manusia yang dimiliki perusahaan.

\section{d. Tingkat Kepuasan Kerja, Semangat Kerja dan Produktivitas Kerja Pegawai di Suatu Perusahaan Instansi atau Organisasi}

Pada dasarnya seseorang dalam bekerja akan merasa nyaman pada perusahaan apabila memperoleh kepuasan kerja. Kinerja seseorang akan dipengaruhi oleh tingkat kepuasan kerja yang dimiliki. Ketika karyawan merasakan kepuasan terhadap pekerjaan yang dilakukan. Maka karyawan tersebut akan bekerja secara maksimal dalam menyelesaikan pekerjaanya, bahkan melakukan beberapa hal yang mungkin diluar tugasnya. Begitu juga ketika seseorang mempunyai komitmen yang tinggi terhadap perusahaannya karena keyakinan terhadap organisasinya. 
Dalam teori kepuasan kerja menurut Valur Theory teori ini kepuasan kerja terjadi pada tingkatan dimana hasil pekerjaan diterima individu seperti diharpkan. Semakin banyak orang menerima hasil, akan semakin puas dan sebaliknya.

Kepuasan kerja berkorelasi dengan semangat kerja, jika kepuasan kerja tinggi maka semangat kerja akan meningkat, dan sebaliknya jika tingkat kepuasan kerja pegawai rendah maka semangat kerja pegawaipun akan menurun. Perusahaan yang diperkuat dengan semangat kerja pegawai akan berbanding lurus dengan produktivitas dan prestasi kerja pegawai tersebut yang pada akhirnya akan berpengaruh pada pertumbuhan perusahaan tersebut. Oleh karena itu, perusahaan perlu menjaga semangat kerja pegawai agar tetap stabil. Jika pegawai memiliki tingkat semangat kerja yang baik maka pekerjaan pegawai yang dijalanipun akan cepat terselesaikan serta melakukan pekerjaan dengan lebih giat dan maksimal.

\section{e. Pengaruh Serta Pentingnya Faktor Kepuasan Kerja dan Semangat Kerja dalam Meningkatkan Produktivitas Kerja Pegawai}

Kepuasan kerja mempengaruhi produktivitas kerja, jika kepuasan kerja naik maka otomatis produktivitas kerja pegawai akan ikut naik.semangat kerja mempengaruhi produktivitas kerja, jika semangat kerja naik maka secara otomatis produktivitas kerja pegawai akan ikut naik. Kepuasan kerja dan semangat kerja secara bersama-sama mempengaruhi produktivitas kerja, jika kepuasan kerja dan semnagat kerja pegawai naik maka secara otomatis produktivitas kerja pegawai pun juga akan ikut naik. Semangat kerja mempengaruhi produktivitas kerja, dimana dengan semangat kerja yang tinggi maka karyawan diharapkan akan mencapai tingkat produktivitas yang lebih baik, dan pada akhirnya menunjang terwujudnya tujuan dari perusahaan. 
Dalam buku Manajemen Kinerja (Wibowo, 2017) Pengaruh kepuasan kerja, minat manajer dalam kepuasan kerja cenderung berpusat pada pengaruhnya terhadap kepuasan kerja. Dampak kepuasan kerja pada produktivitas, Pekerja yang bahagia tidak berarti menjadi pekerja yang produktif. Pada tingkat individual, kenyataan menganjurkan sebaliknya untuk lebih akurat, produktivitas mungkin mengarah pada kepuasan.

Faktor kepuasan kerja dan semangat kerja sangat berpengaruh dan sangat penting dalam meningkatkan produktivitas kerja karywan dalam suatu perusahan atau organisasi, karena dengan adanya kepuasan kerja serta semngat kerja karyawan yang tinggi maka akan berdampak pada peningkatan produktivitas suatu perusahaan atau organisasi tersebut.

Kepuasan kerja dan semangat kerja sangat penting bagi karyawan untuk meningkatkan produktivitas kerja karyawan itu sendiri. Apabila kepuasan kerja itu tidak tercapai dan karyawan menganggap kerja sebagai beban maka tidak akan mencapai hasil kerja yang maksimal. Kepuasan kerja itu belum sepenuhnya dirasakan oleh seluruh karayawan

Adapun upaya upaya terhadap peningkatan produktivitas kerja yaitu: Menurut Siagian (2009: 36) upaya terhadap peningkatan kerja secara keseluruhan baik pegawai maupun lembaga harus mempertimbangkan hal berikut yaitu: kejelasan tujuan, fungsionalisasi, pembagian tugas, penempatan yang tepat, koordinasi departementalisasi, kesatuan arah, kesatuan komando, rentang kendali, pola pengambilan keputusan. Upaya yang dilakukan untuk meningkatkan produktivita adalah melalui pendkatan sumber daya manusia yaitu dengan mengadakan penyempurnaan struktur organisasi, pengembangan sumber daya manusia dan motivasi terapan atau kegiatan yang dapat mendorong pegawai untuk bekerja dengan giat dan lebih bersemangat. 


\section{PENUTUP}

\section{Kesimpulan}

Berdasarkan pembahasan diatas maka dapat kita simpulkan bahwa antara kepuasan kerja, semangat kerja, serta produktivitas kerja saling berpengaruh dan saling berhubungan satu sama lain, antara lain sebagai berikut:

(1) Kepuasan kerja adalah sika atau perasaan seorang individu atau pegawai yang menyenangkan dan tidak menyenagkan yang berhubungan dengan pekerjaannya ataupun kondisi diri individu itu sendiri. (2) Semangat kerja adalah keinginan dan kesungguhan seseorang dalam menjalankan pekerjaanya dengan baik giat serta disiplin untuk mencapai tujuan yang telah ditetapkan secara optimal. (3) Produktivitas kerja adalah ukuran efisiensi dan efektivitas produktif. produktivitas kerja merupakan perbandingan yang dimiliki baik secara peroragan ataupun tim di dalam orgnisasi tersebut. (4) Kepuasan kerja dan semangat kerja sangat berpengaruh dan sangat penting dalam meningkatkan produktivitas kerja pegawai di suatu perusahaan atau organisasi dimana jika kepuasan kerja dan semangat kerja pegawai di suatu perusahaan naik, maka secara otomatis produktivitas kerja pegawai juga akan ikut naik.

\section{Saran}

Berdasarkan pembahasan dan kesimpulan yang telah diuraikan ditas, maka saran yang dapat disampaikan adalah sebagai berikut:

(1) Setiap orang bekerja mengharapkan memperoleh kepuasan dari tempat kerjanya. Kepuasan kerja akan mempengaruhi produktivitas yang sangat diharapkan manajer, untuk itu, manajer perlu memahami apa yang harus dilakukan untuk menciptakan kepuasan kerja karyawannya. (2) Kepuasan pegawai perlu ditingkat misalnya dengan memperhatikan faktor jaminan kesehatan, pemberian uang lembur, dan pemaksimalan waktu kerja, serta memberikan pegawai dapat memberikan pegawasan yang baik agar pegawai 
dapat memberikan produktivitas secara optmal. (3) Semangat kerja pegawai perlu ditingkatkan dengan menempatkan rekan kerja sesuai dengan kemampuan yang dimiliki pegawai dan membina hubungan kerja sama antar dalam pelaksanaan tugas. (4) Untuk meningkatkan produktivitas kerja pegawai perlu adanya penambahan fasilitas dan tata ruang kerja yang mendukung dalam pekerjaan. Oleh sebab itu instansi harus mengetahui kebutuhan, fasilitas dan kelengkapan tata ruang kerja apa saja yang dibutuhkan pegawai, sehingga pegawai dapat bekerja dengan maksimal.

\section{DAFTAR PUSTAKA.}

Mangkunegara, A. P. (1993). Psikologi Perusahaan. Bandung: Trigenda Kriya.

Sutrisno, E. (2009). Manajemen Sumber Daya Manusia. Jakarta: Kencana.

Wibowo. (2017). Manajemen Kinerja. Depok: Rajawali Pers.

Ermita. 2012. "Hubungan Antar Manusia Dan Semangat Kerja Pegawai.” Pedagogi, Jurnal Ilmiah Ilmu Pendidikan XII(2): 70-81.

Ilahi, Dede Kurnia, Mochamad Djudi Mukzam, and Arik Prasetya. 2017. "Pengaruh Kepuasan Kerja Terhadap Disiplin Kerja Dan Komitmen Organisasional (Studi Pada Karyawan PT.PLN (Persero) Distribusi Jawa Timur Area Malang).” Jurnal Administrasi Bisnis S1 Universitas Brawijaya 44(1): 31-39.

Wibisono, Albertus Agung. 2017. "Pengaruh Kepuasan Kerja Dan Semangat Kerja Terhadap Komitmen Organisasi Dan Organizational Citizenship Behavior (Ocb) Pada Karyawan Hotel Comfort Dumai.” Jurnal Online Mahasiswa Fakultas Ekonomi Universitas Riau 4(1): 616-29. 